\title{
Przeżycia chorych na niedrobnokomórkowego raka płuca leczonych napromienianiem w latach 2003-2006 w Samodzielnym Publicznym Zakładzie Opieki Zdrowotnej Ministerstwa Spraw Wewnętrznych z Warmińsko-Mazurskim Centrum Onkologii w Olsztynie
}

\author{
Karolina Osowiecka1 , Monika Rucińska1,2, Andrzej Każarnowicz ${ }^{3}$, Sergiusz Nawrocki ${ }^{4}$
}

\begin{abstract}
Wstęp. W Polsce rak płuca jest jednym z najgorzej rokujących nowotworów i stanowi najczęstszą przyczynę zgonów z powodu nowotworów złośliwych. Celem analizy była ocena skuteczności leczenia chorych na niedrobnokomórkowego raka płuca (NDRP) w Samodzielnym Publicznym Zakładzie Opieki Zdrowotnej Ministerstwa Spraw Wewnętrznych z Warmińsko-Mazurskim Centrum Onkologii w Olsztynie prowadzonego w latach 2003-2006 (pierwsze 4 lata działalności ośrodka).

Materiał i metody. Analizą objęto wszystkich pacjentów (801) leczonych napromienianiem z powodu NDRP w latach 2003-2006 (w stopniu klinicznego zaawansowania I-IV, leczonych radykalnie i paliatywnie).

Wyniki. Dwu- i pięcioletnie przeżycia całkowite (OS) wszystkich chorych wyniosły 19\% i 7\% (mediana: 7 miesięcy). Dwu- i pięcioletnie OS osób leczonych radykalnie wyniosły 43\% i 18\% (mediana: 1 rok i 9 miesięcy). Lepiej rokowały kobiety $(p=0,075)$. Nie wykazano istotnego statystycznie wpływu stopnia klinicznego zaawansowania, cechy $\mathrm{T}$, rozpoznania histopatologicznego i czasu trwania radiochemioterapii na OS pacjentów poddanych radiochemioterapii. Zajęcie węzłów chłonnych okazało się być istotne dla rokowania: N0 vs N2 ( $p=0,017)$ i N1 vs N2 ( $p=0,008)$. Nie wykazano wpływu dawki całkowitej na rokowanie pacjentów poddanych radykalnej radioterapii ( $\leq 60 \mathrm{~Gy} v s>60 \mathrm{~Gy}$ ). Wnioski. Na przeżycia analizowanej grupy osób nie miały wpływu: płeć, stopień klinicznego zaawansowania, cecha T, rozpoznanie histopatologiczne, dawka i czas trwania radiochemioterapii. Jedynie zajęcie węzłów chłonnych miało istotne statystycznie znaczenie.
\end{abstract}

Survival of patients treated with radiation for non-small-cell lung cancer in Samodzielny Publiczny Zakład Opieki Zdrowotnej Ministerstwa Spraw Wewnętrznych z Warmińsko-Mazurskim Centrum Onkologii in Olsztyn between 2003 and 2006

Introduction. In Poland lung cancer has a very poor prognosis and it is the most common cause of cancer deaths. Our aim was to study survival analysis of patients treated for non-small-cell lung cancer (NSCLC) in Samodzielny Publiczny Zakład Opieki Zdrowotnej Ministerstwa Spraw Wewnętrznych z Warmińsko-Mazurskim Centrum Onkologii in Olsztyn between 2003 and 2006 (the initial 4 years of Centre activity).

\footnotetext{
${ }^{1}$ Zakład i Oddział Radioterapii

Samodzielny Publiczny Zakład Opieki Zdrowotnej Ministerstwa Spraw Wewnętrznych z Warmińsko-Mazurskim Centrum Onkologii w Olsztynie

${ }^{2}$ Katedra Onkologii

Uniwersytet Warmińsko-Mazurski w Olsztynie, Wydział Nauk Medycznych

${ }^{3}$ Oddział Onkologii i Chemioterapii Nowotworów Płuc

Samodzielny Publiczny Zespół Gruźlicy i Chorób Płuc w Olsztynie

${ }^{4}$ Katedra Onkologii i Radioterapii

Śląski Uniwersytet Medyczny
} 
Material and methods. The analysis included all patients (801) treated with radiation for NSCLC between 2003 and 2006 (I-IV clinical stages, treated with radical or palliative radiotherapy).

Results. Overall 2-year and 5-year survival (OS) of all patients was 19\% and 7\% (median 7 months). Two-year and five-year OS of patients treated with radical intent was $43 \%$ and $18 \%$ (median 1 year and 9 months). There was a trend for better prognosis in women $(p=0.075)$. There was no significant influence of clinical stage, tumour size, histopathology, radiotherapy dose ( $\leq 60$ Gy versus $>60 \mathrm{~Gy}$ ) or duration of chemoradiotherapy on survival in chemoradiotherapy group ( $p>0.05)$. The only statistically significant factor was lymph node involvement: N0 versus N2 $(p=0.017)$ and N1 versus N2 ( $p=0.008)$.

Conclusions. There was no statistically significant influence of sex, clinical stage, tumour size, histopathology, dose and duration of chemoradiotherapy on OS. The only statistically significant factor was lymph node involvement.

NOWOTWORY Journal of Oncology 2015; 65, 1: 14-22

Słowa kluczowe: NDRP, radiochemioterapia, radioterapia, 2-letnie i 5-letnie przeżycia całkowite

Key words: NSCLC, chemoradiotherapy, radiotherapy, 2-year and 5-year overall survival

\section{Wstęp}

W Polsce rak płuca jest najczęstszym nowotworem złośliwym u mężczyzn i drugim co do częstości występowania u kobiet. Rak płuca jest jednym z najgorzej rokujących nowotworów i stanowi najczęstszą przyczynę zgonów z powodu raka u obu płci [1]. Obecnie około $80-85 \%$ wszystkich nowotworów złośliwych płuca stanowi niedrobnokomórkowy rak płuca (NDRP) [2, 3]. Pięcioletnie przeżycia chorych na NDRP, w zależności od stopnia zaawansowania nowotworu, mieszczą się w granicach 4-66\% [4]. Jedną z przyczyn złego rokowania jest późne rozpoznanie - większość chorych nie kwalifikuje się do radykalnego leczenia chirurgicznego [5].

Celem niniejszej analizy była ocena skuteczności leczenia chorych na NDRP w Samodzielnym Publicznym Zakładzie Opieki Zdrowotnej Ministerstwa Spraw Wewnętrznych z Warmińsko-Mazurskim Centrum Onkologii w Olsztynie (SP ZOZ MSW z W-MCO w Olsztynie) prowadzonego w latach 2003-2006 (pierwsze 4 lata działalności ośrodka). W Polsce nadal brakuje publikacji przedstawiających wyniki skuteczności leczenia w poszczególnych ośrodkach onkologicznych.

\section{Materiał i metody}

Analizą objęto wszystkich chorych z rozpoznaniem NDRP leczonych napromienianiem w SP ZOZ MSW z W-MCO w Olsztynie w latach 2003-2006. W tej grupie znaleźli się pacjenci w stopniu zaawansowania klinicznego I-IV wg klasyfikacji TNM (UICC 2003), leczeni z intencją radykalną i paliatywną. Pacjenci leczeni radykalnie otrzymali radioterapię lub radiochemioterapię jako leczenie samodzielne bądź pooperacyjne. Uwzględniono także pacjentów napromienianych z powodu wznowy miejscowej po uprzednim leczeniu operacyjnym. Baza danych Lantis, wykorzystywana w Zakładzie Radioterapii SP ZOZ MSW z W-MCO w Olsztynie, posłużyła do wygenerowania listy chorych. Dane o śmierci pacjentów uzyskano z Warmińsko-Mazurskiego Rejestru
Nowotworów w Olsztynie oraz z Centrum Personalizacji Dokumentów Ministerstwa Spraw Wewnętrznych Wydziału Udostępniania Danych w Warszawie. Pozostałe dane wykorzystane do analizy pochodziły z dokumentacji medycznej oraz bazy danych Lantis. Sporządzono bazę danych w programie STATISTICA (wersja 10; 2012 r.) i za jego pomocą przeprowadzono analizy przeżyć pacjentów, mierzone od daty rozpoczęcia leczenia (dla pacjentów leczonych radykalnie od pierwszego dnia chemioterapii lub radioterapii, o ile wcześniejsza chemioterapia nie była stosowana; dla pacjentów leczonych paliatywnie — od pierwszego dnia radioterapii) do daty ostatniej obserwacji (śmierci). Za pomocą metody Kaplana-Meiera oceniono wpływ zmiennych o charakterze kategoryzowanym na czas przeżycia chorych, a istotność statystyczną uzyskanych zależności oceniono za pomocą testu log-rank. Za statystycznie znamienne przyjęto wartości $p \leq 0,05$. Dla oceny wpływu zmiennej niekategoryzowanej (czas trwania radiochemioterapii) na przeżycia całkowite (OS) wykorzystano model regresji Coxa (współczynnik ryzyka względnego $R R>1 ; p \leq 0,05)$.

\section{Wyniki}

W latach 2003-2006 w SP ZOZ MSW z W-MCO w Olsztynie leczono napromienianiem 801 pacjentów chorych na NDRP. 81 pacjentów (10\% wszystkich analizowanych) było leczonych w ramach randomizowanego badania klinicznego II fazy "Concurrent chemotherapy and short course radiotherapy in patients with stage IIIA to IIIB non-small cell lung cancer not eligible for radical treatment" [6] (tab. I). Spośród wszystkich leczonych osób kobiety stanowiły $20 \%$ (162), a mężczyźni 80\% (639). Rozpiętość wieku leczonych pacjentów była duża (28-85 lat). Kobiety były nieco młodsze niż mężczyźni (kobiety: 35-85 lat, mediana 59 lat, średnia wieku 60 lat, odchylenie standardowe 10,1 roku; mężczyźni: 28-85 lat, mediana 64 lata, średnia wieku 63 lat, odchylenie standardowe 9,5 roku). 
Tabela I. Sposób leczenia wszystkich 801 pacjentów

\begin{tabular}{lcc}
\hline Sposób leczenia & Liczba & $\%$ \\
\hline Wszyscy pacjenci & 801 & 100 \\
Leczenie radykalne & 193 & 24 \\
Radioterapia samodzielna & 28 & 14,5 \\
Radiochemioterapia & 126 & 65,5 \\
sekwencyjna & 121 & 63 \\
jednoczasowa & 5 & 2,5 \\
Radioterapia pooperacyjna & 29 & 15 \\
samodzielna & 15 & 8 \\
z chemioterapią & 14 & 7 \\
Radioterapia z powodu wznowy po operacji & 10 & 5 \\
samodzielna & 4 & 2 \\
z chemioterapią & 6 & 3 \\
Radioterapia paliatywna & 527 & 66 \\
Badanie kliniczne & 81 & 10 \\
\hline
\end{tabular}

Jedna czwarta analizowanych chorych z rozpoznaniem NDRP otrzymała napromienianie z intencją radykalną (tab. I). Nie zaobserwowano różnicy w odsetkach leczonych radykalnie zależnej od płci (27\% kobiet i 23\% mężczyzn). Najwięcej osób leczonych napromienianiem z założeniem radykalnym (130 pacjentów, 67,4\%) było w IIIA-IIIB stopniu zaawansowania klinicznego. Trzech pacjentów było w IV stopniu zaawansowania klinicznego (bez przerzutów odległych, z płynem w opłucnej lub satelitarnym guzkiem w tym samym płucu). U większości pacjentów leczonych radykalnie stwierdzono kliniczną lub patologiczną cechę $\mathrm{N}(+)$ (134 pacjentów, 70\%). Pod względem rozpoznania histopatologicznego dominował rak płaskonabłonkowy, który stanowił 62\% (120 przypadków). U trzech chorych nie uzyskano weryfikacji histopatologicznej (u jednego chorego z powodu zespołu żyły głównej górnej, dwóch chorych nie wyraziło zgody na inwazyjną diagnostykę) (tab. II).

Większość chorych leczonych napromienianiem w tutejszym ośrodku w analizowanym okresie nie była operowana (154 pacjentów, 80\% leczonych radykalnie), z czego 126 pacjentów otrzymało radiochemioterapię, a 28 pacjentów samodzielną radioterapię (tab. I). Zdecydowana większość osób poddanych radiochemioterapii (106 pacjentów, 85\%) była w stopniu klinicznego zaawansowania IIIA-IIIB, u prawie połowy chorych (58 pacjentów, 46\%) guz był oceniony jako T4, większość chorych (103 pacjentów, 82\%) miała zajęte węzły chłonne, w tej grupie płaskonabłonkowy rak płuca stanowił $68 \%$. Natomiast większość pacjentów, którzy otrzymali wyłącznie radioterapię (22 pacjentów, 78\%), była w stopniu IA-IB, większość chorych (23 pacjentów, 82\%) nie miała zajętych węzłów chłonnych, płaskonabłonkowy rak płuca stanowił w tej grupie połowę przypadków (53\%).

Dwudziestu dziewięciu pacjentów (15\% pacjentów leczonych napromienianiem z intencją radykalną) było pier-
Tabela II. Podział pacjentów leczonych radykalnie ze względu na stopień zaawansowania klinicznego, zaawansowanie guza pierwotnego (T) i regionalnych węzłów chłonnych (N) wg klasyfikacji TMN (UICC 2003r.) oraz na rozpoznanie histopatologiczne wg klasyfikacji histologicznej Światowej Organizacji Zdrowia

\begin{tabular}{|c|c|c|}
\hline Wszyscy pacjenci leczeni radykalnie (193) & Liczba & $\%$ \\
\hline \multicolumn{3}{|l|}{ Cecha T } \\
\hline T1 & 17 & 9 \\
\hline $\mathrm{T} 2$ & 72 & 37 \\
\hline T3 & 44 & 23 \\
\hline T4 & 60 & 31 \\
\hline \multicolumn{3}{|l|}{ Cecha N } \\
\hline No & 59 & 30 \\
\hline N1 & 34 & 18 \\
\hline N2 & 87 & 45 \\
\hline N3 & 13 & 7 \\
\hline \multicolumn{3}{|l|}{ Stopień zaawansowania klinicznego } \\
\hline $\mathrm{IA}$ & 13 & 6,7 \\
\hline IB & 23 & 11,9 \\
\hline IIA & 1 & 0,5 \\
\hline IIB & 23 & 11,9 \\
\hline IIIA & 65 & 33,7 \\
\hline IIIB & 65 & 33,7 \\
\hline IV & 3 & 1,6 \\
\hline \multicolumn{3}{|l|}{ Rozpoznanie histopatologiczne } \\
\hline Rak płaskonabłonkowy & 120 & 62 \\
\hline Rak gruczołowy & 49 & 25,5 \\
\hline Rak wielkokomórkowy & 6 & 3 \\
\hline Rak niedrobnokomórkowy niesklasyfikowany & 15 & 8 \\
\hline Brak potwierdzenia histopatologicznego & 3 & 1,5 \\
\hline
\end{tabular}

wotnie poddanych leczeniu operacyjnemu, a następnie samodzielnej radioterapii lub radiochemioterapii. U dwóch pacjentów zastosowano 2 kursy chemioterapii neoadiuwantowej, poprzedzającej leczenie operacyjne. Ponad połowa pacjentów poddanych radioterapii pooperacyjnej (17 pacjentów, 58,5\%) otrzymała leczenie z powodu mikroskopowego nieradykalizmu zabiegu (R1) (w tym u czterech pacjentów stwierdzono cechę pN2, a u dwóch pacjentów dodatkowo występowało naciekanie opłucnej płucnej i opłucnej ściennej). Pozostali pacjenci otrzymali pooperacyjną radioterapię z następujących powodów: dziewięciu chorych (31\%) z powodu cechy pN2 (w tym u 3 też naciek na opłucną), po jednym chorym (3,5\%) jedynie z powodu nacieku na opłucną, z powodu nacieku na żebra, z powodu nacieku na przeponę.

Dziesięciu chorych (5\%) otrzymało napromienianie z powodu wznowy miejscowej po operacji, z czego dwóch pacjentów z powodu wznowy miejscowej wczesnej (2-4 miesiące po operacji) i ośmiu pacjentów z powodu wznowy miejscowej późnej (od 9 miesięcy do 12 lat po operacji). 


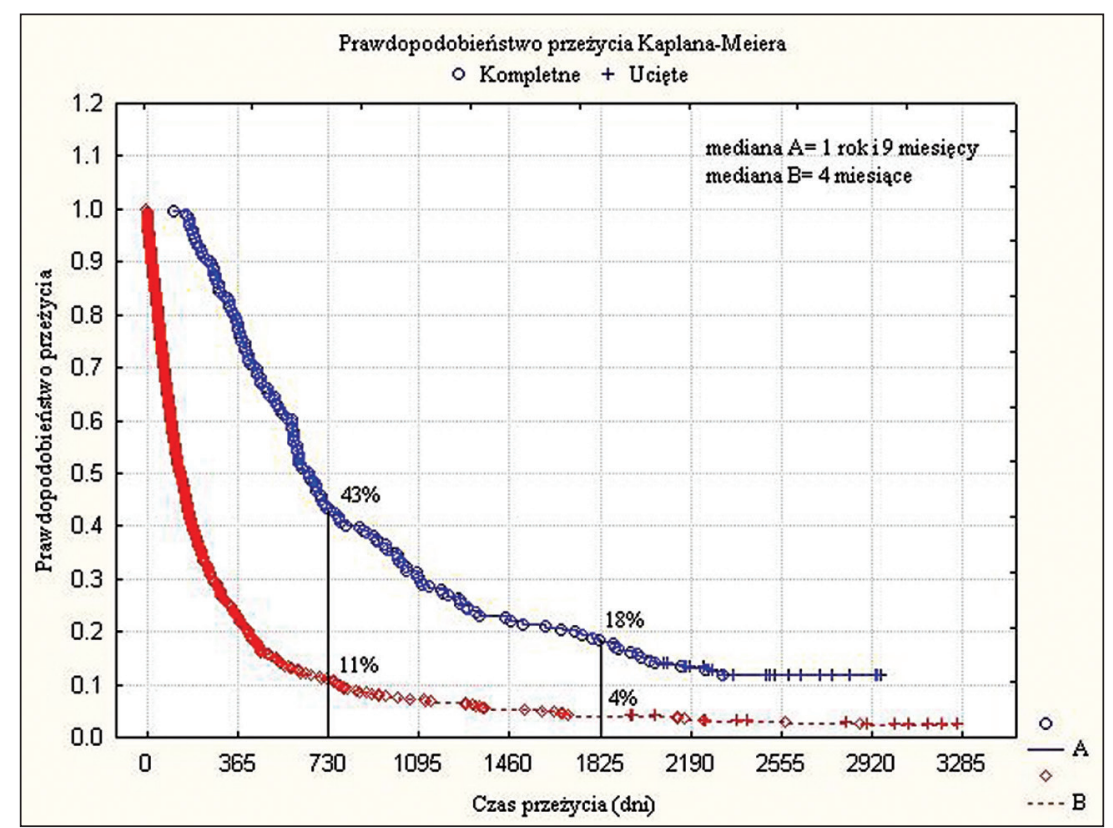

Rycina 1. Krzywa przeżycia całkowitego pacjentów leczonych napromienianiem z intencją: A — radykalną (187 chorych ze 193 ; u 6 chorych nie udało się ustalić daty rozpoczęcia chemioterapii, co uniemożliwia włączenie ich do analizy); B - paliatywną (527)

Radioterapię przeprowadzono przy użyciu fotonów o energii 6 MV, uzyskanych w akceleratorze liniowym. Stosowano planowanie leczenia 3D. Obszar PTV obejmował guz i odpowiednie węzły chłonne śródpiersia. U 125 pacjentów poddanych radioterapii samodzielnej lub skojarzonej z chemioterapią zaplanowano podanie 66 Gy w 33 frakcjach w dawce frakcyjnej 2 Gy. Siedmiu pacjentów nie otrzymało pełnej dawki (jeden pacjent zakończył leczenie na dawce 64 Gy z powodu awarii aparatu, u dwóch pacjentów zakończono leczenie z powodu pogorszenia stanu ogólnego na dawce 56 Gy i 28 Gy, u jednego pacjenta w trakcie radioterapii stwierdzono progresję miejscową choroby i zakończono leczenie na dawce 50 Gy, dwóch pacjentów nie zakończyło zaplanowanego leczenia z powodu stwierdzenia przerzutów odległych: jeden chory otrzymał dawkę 40 Gy (przerzuty do mózgu), kolejny chory otrzymał dawkę 42 Gy (przerzuty do kości), jeden pacjent samodzielnie przerwał leczenie na dawce 58 Gy). Osiemnastu pacjentów otrzymało 60 Gy we frakcjonacji po 3 Gy. Trzech pacjentów otrzymało 45-50 Gy we frakcjonacji po 2,5 Gy. U dwóch pacjentów, którzy byli kandydatami do leczenia pierwotnie operacyjnego, zaplanowano podanie 70 Gy w 35 frakcjach (jeden pacjent nie wyraził zgody na leczenie chirurgiczne i otrzymał pełną dawkę radioterapii, drugi pacjent miał bezwzględne przeciwwskazania do operacji, jednak z powodu pogorszenia stanu ogólnego zakończono jego leczenie na dawce 54 Gy). U czterech pacjentów zastosowano 60 Gy, a u jednego pacjenta 50 Gy we frakcjonacji po 2 Gy. Jeden chory otrzymał 54 Gy w 18 frakcjach w dawce frakcyjnej 1,8 Gy i dodatkowo dawkę 6 Gy z brachyterapii. 29 chorych napromienianych pooperacyjnie otrzymało 50-66 Gy w dawce frakcyjnej 2 Gy. Spośród 10 pacjentów leczonych z powodu wznowy miejscowej 8 chorych otrzymało 60-66 Gy w 30-33 frakcjach po 2 Gy. Dwóch chorych otrzymało 60 Gy w dawce frakcyjnej 3 Gy.

Całkowity czas trwania leczenia z założeniem radykalnym (od początku radioterapii lub radiochemioterapii do jej zakończenia) wyniósł 2,6-71 tygodni (mediana 16 tygodni, średni czas 15 tygodni, odchylenie standardowe 9 tygodni). W przypadku radiochemioterapii u 121 pacjentów (96\% poddanych radiochemioterapii) radioterapię rozpoczynano po zakończeniu chemioterapii (1-6 kursów), jedynie u 5 pacjentów radioterapię stosowano równocześnie z chemioterapią (podając 1-2 kursy w trakcie radioterapii) (tab. I).

\section{Analiza przeżyć}

Spośród wszystkich 801 pacjentów leczonych napromienianiem z powodu niedrobnokomórkowego raka płuca w SP ZOZ MSW z W-MCO w Olsztynie w latach 2003-2006 wyłączono 6 pacjentów, ponieważ nie udało się ustalić daty rozpoczęcia chemioterapii, co uniemożliwia określenie OS. Dwuletnie OS 187 pacjentów ze 193 leczonych z założeniem radykalnym wyniosły 43\%, 5-letnie OS wyniosły 18\% (mediana przeżyć 1 rok i 9 miesięcy). Dwuletnie przeżycia całkowite dla chorych leczonych napromienianiem z intencją paliatywną z powodu NDRP wyniosły 11\%, 5-letnie - 4\% (mediana przeżyć 4 miesiące) (ryc. 1).

Dwu-i pięcioletnie OS 150 pacjentów ze 154 poddanych radykalnej samodzielnej radioterapii lub radiochemioterapii, po wyłączeniu chorych leczonych uzupełniająco poopera- 


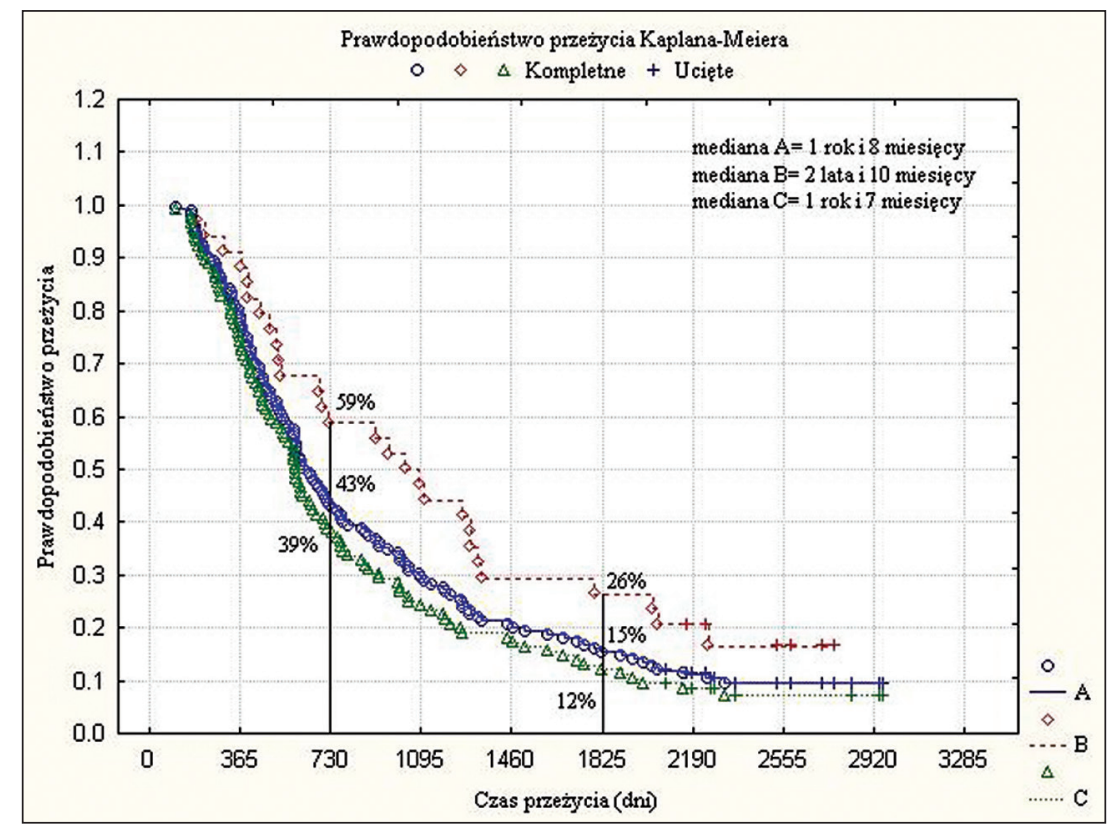

Rycina 2. Krzywa przeżycia całkowitego pacjentów poddanych radykalnej radioterapii samodzielnej i radiochemioterapii (150 chorych ze 154 ; u 4 chorych nie udało się ustalić daty rozpoczęcia chemioterapii, co uniemożliwia włączenie ich do analizy). A - pacjenci leczeni napromienianiem bez uprzedniej operacji/nawrotu choroby (150); B — kobiety (34); C - mężczyźni (116)

cyjnie lub z powodu nawrotu choroby po wcześniejszej operacji, wyniosły odpowiednio 43\% i 15\% (mediana przeżyć 1 rok i 8 miesięcy). Przeprowadzono analizę porównawczą zależną od płci. Dwu- i pięcioletnie przeżycia całkowite kobiet wyniosły odpowiednio 59\% i 26\% (mediana przeżyć 2 lata i 10 miesięcy), natomiast w przypadku mężczyzn wyniosły odpowiednio 39\% i 12\% (mediana przeżyć 1 rok i 7 miesięcy) (różnice pomiędzy tymi grupami są znamienne statystycznie; $p=0,009$ ) (ryc. 2).

W grupie osób leczonych radykalnie nie zaobserwowano różnicy w przeżyciach dwuletnich i medianie przeżyć w zależności od zastosowanych dawek całkowitych radioterapii ( $\leq 60$ Gy vs > 60 Gy) - 2-letnie OS odpowiednio $44 \%$ vs 43\%; mediana dla obu przedziałów dawek: 1 rok i 9 miesięcy, ale po dłuższej obserwacji widoczna jest tendencja do poprawy przeżyć w przypadku zastosowania niższych dawek (5-letnie OS wyniosło odpowiednio 21\% vs 16\%, p = 0,54).

Przeprowadzono analizę porównawczą zależną od stosowania chemioterapii. Dwu- i pięcioletnie przeżycia chorych poddanych samodzielnej radioterapii wyniosły $61 \%$ i 22\% (mediana: 2 lata i 2 miesiące), a w przypadku radiochemioterapii wyniosły odpowiednio 56\% i 13\% (mediana: 2 lata i 4 miesiące). Pacjenci z cechą No rokowali tak samo niezależnie od sposobu leczenia (samodzielna radioterapia vs radiochemioterapia) $(\mathrm{p}=0,76)$. Wszyscy pacjenci (oprócz 5) z cechą $\mathrm{N}(+)$ otrzymali radiochemioterapię.

W wyniku przeprowadzonej analizy 122 pacjentów ze 126 poddanych wyłącznie radiochemioterapii (u 4 pacjentów nie udało się określić daty rozpoczęcia chemioterapii) 2-i 5-letnie OS wyniosły odpowiednio 39\% i 12\% (mediana przeżyć 1 rok i 7 miesięcy). Natomiast dla pacjentów w stadium zaawansowania IIIA-IIIB wyniosły 37\% i 13\% odpowiednio po 2 i 5 latach (mediana przeżyć 2 lata i 4 miesiące). Przeprowadzono analizę porównawczą grupy pacjentów poddanych radiochemioterapii różniących się stopniem klinicznego zaawansowania. Nie wykazano istotnych statystycznie różnic pomiędzy grupami chorych w stopniu klinicznego zaawansowania IIB/IIIA/IIIB ( $p>0,05$, mediana przeżyć około 1,5 roku). Nie uwzględniono pacjentów w stopniu I i IV ze względu na małą liczebność grup (odpowiednio 4 i 3 pacjentów). Wykazano, że sama cecha T również nie wpływa na przeżycia ( $p>0,05$; mediana przeżyć nieco powyżej 1,5 roku). Natomiast pacjenci, którzy nie mieli zajętych węzłów chłonnych, rokują lepiej. Mediana przeżyć pacjentów z cechą N0 wyniosła 2 lata i 4 miesiące i była dłuższa prawie o rok w porównaniu z grupą pacjentów z cechą N1-3. Dwu- i pięcioletnie OS pacjentów z cechą N(-) i N(+) wyniosły odpowiednio $57 \%$ vs 34\% i $18 \%$ vs $12 \%$. Statystycznie znamienne różnice wykazano pomiędzy grupami chorych z cechą N0 vs N2 ( $p=0,017)$ i N1 vs N2 ( $p=0,008)$ (ryc. 3).

Zaobserwowano różnicę w przeżyciach dwuletnich zależną od rozpoznania histopatologicznego. Mediana przeżyć pacjentów z rakiem gruczołowym była o rok dłuższa niż pacjentów z rakiem płaskonabłonkowym (2,5 roku vs 1,5 roku). Odsetek 2-letnich OS był lepszy dla pacjentów z rakiem gruczołowym ( $52 \%$ vs 36\%), jednak 5-letnie OS były identyczne, wobec czego ostateczne różnice w przeżyciach nie okazały się znamienne ( $p=0,23$ ) (ryc. 4).

Nie wykazano istotnego statystycznie wpływu czasu trwania radiochemioterapii (32-497 dni; średni czas 134 dni; 


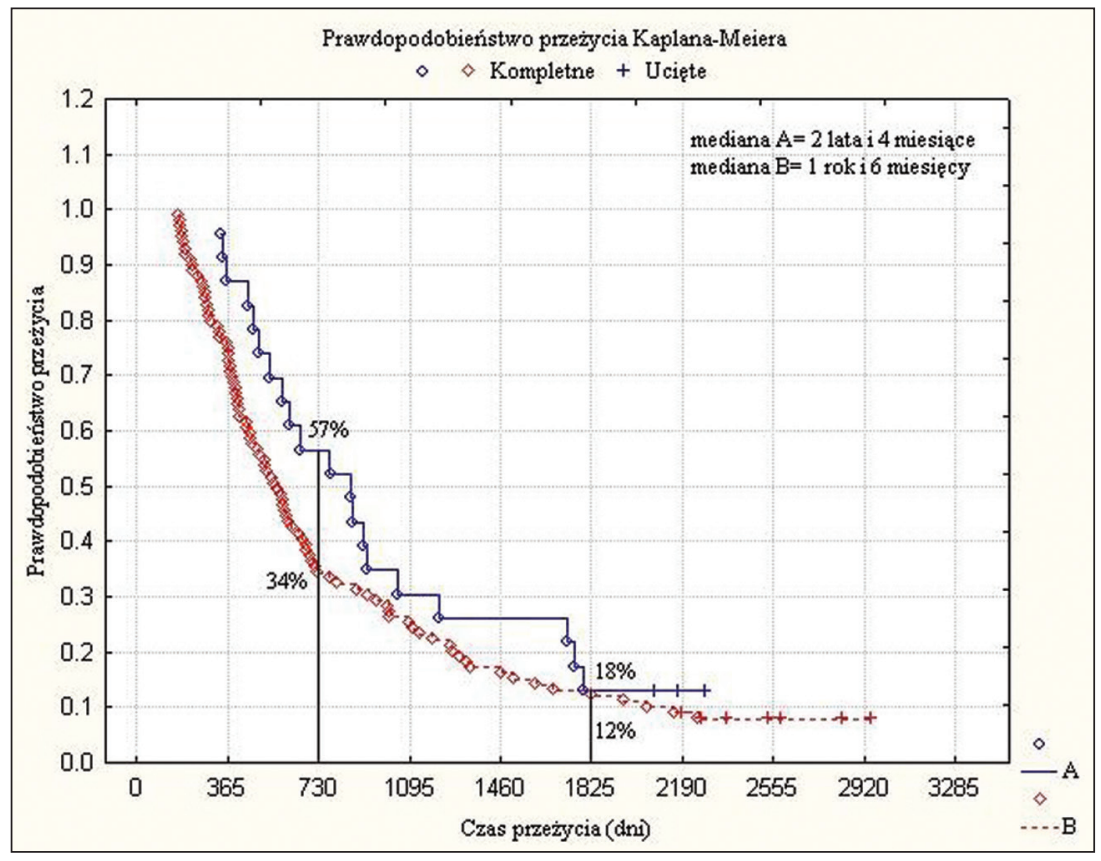

Rycina 3. Krzywe przeżycia całkowitego dla pacjentów poddanych radykalnej radiochemioterapii (122 chorych ze 126; u 4 chorych nie udało się ustalić daty rozpoczęcia chemioterapii, co uniemożliwia włączenie ich do analizy). A — 23 pacjentów z cechą N(-); B — 99 pacjentów z cechą N(+)

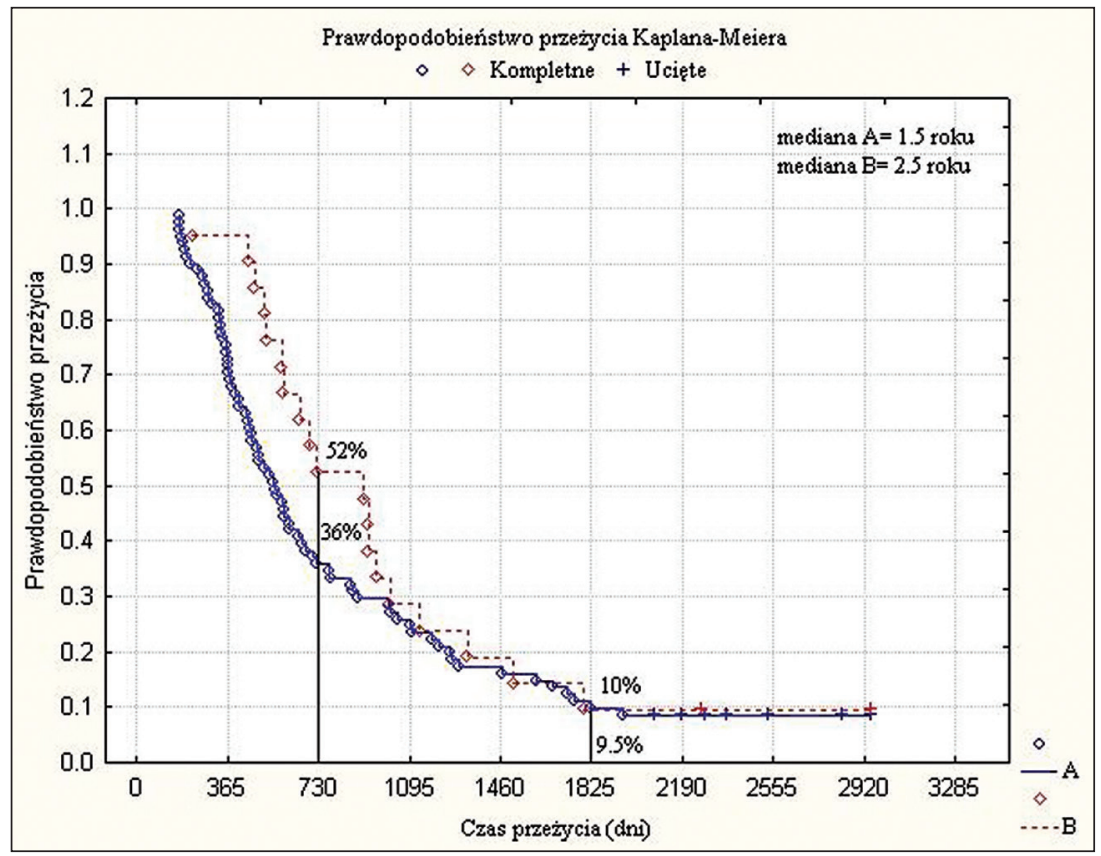

Rycina 4. Krzywe przeżycia całkowitego dla pacjentów poddanych radykalnej radiochemioterapii (102 chorych ze 106; u 4 chorych nie udało się ustalić daty rozpoczęcia chemioterapii, co uniemożliwia włączenie ich do analizy). A - 81 pacjentów z rozpoznaniem raka płaskonabłonkowego; B - 21 pacjentów z rozpoznaniem raka gruczołowego

$\mathrm{SD}=57,23$ dni) na czas przeżycia pacjentów (model regresji proporcjonalnego hazardu Coxa; współczynnik ryzyka względnego $R R=1 ; p=0,25)$.

Pacjenci, którzy byli poddani leczeniu operacyjnemu i na podstawie pooperacyjnego badania histopatologicz- nego zostali zakwalifikowani do leczenia uzupełniającego pod postacią radioterapii lub radiochemioterapii, rokowali analogicznie jak pacjenci pierwotnie zakwalifikowani do radiochemioterapii (mediana przeżyć odpowiednio: 1 rok i 10 miesięcy vs 1 rok i 7 miesięcy) (ryc. 5). Dwu- i pięciolet- 


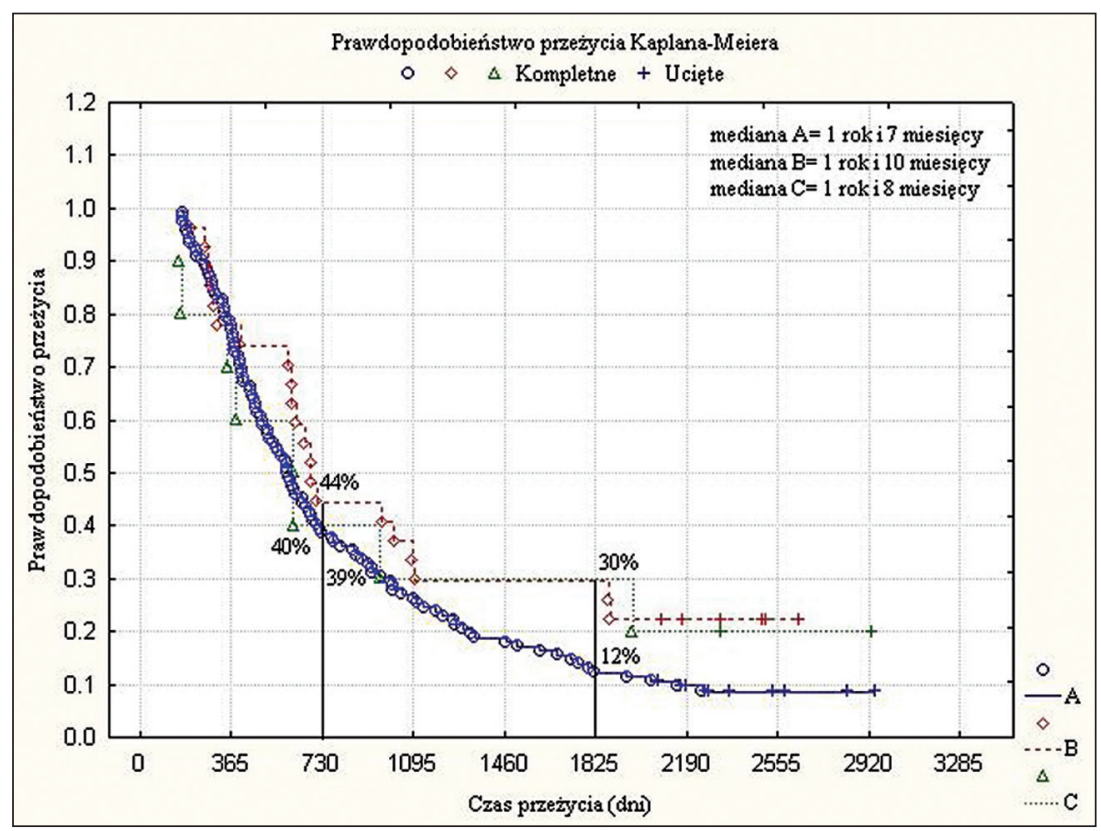

Rycina 5. Krzywa przeżycia całkowitego pacjentów leczonych radykalnie, u których zastosowano: A — radiochemioterapię (122 chorych ze 126; u 4 chorych nie udało się ustalić daty rozpoczęcia chemioterapii); B - leczenie operacyjne z następową radioterapią (27 chorych z $29 ; \mathrm{u} 2$ chorych nie udało się ustalić daty rozpoczęcia chemioterapii); C — napromienianie z powodu wznowy miejscowej pooperacyjnej (10)

nie OS pacjentów leczonych napromienianiem z powodu pooperacyjnej wznowy miejscowej wyniosły odpowiednio 40\% i 30\%. Rokowanie po wznowie po leczeniu chirurgicznym jest takie samo jak w przypadku pierwotnego leczenia radiochemioterapią (mediana przeżyć odpowiednio 1 rok i 8 miesięcy vs 1 rok i 7 miesięcy) (ryc. 5).

\section{Dyskusja}

Niedrobnokomórkowy rak płuca stanowi $80-85 \%$ wszystkich nowotworów złośliwych płuca $[2,3,7]$. Odsetek 5-letnich przeżyć chorych leczonych z powodu NDRP w zależności od stopnia zaawansowania nowotworu (I-IV) mieści się w granicach 4-66\% [4]. Jedną z przyczyn składających się na złe rokowanie raka płuca jest późne rozpoznanie choroby; 80-85\% pacjentów z NDRP ze względu na zaawansowanie kliniczne nie kwalifikuje się do operacji [4, 7-9]. Pięcioletnie przeżycia pacjentów leczonych w SP ZOZ MSW z W-MCO w Olsztynie w latach 2003-2006 wyniosły 7\%. Uzyskane w tutejszym ośrodku wyniki są gorsze w porównaniu z danymi z literatury prawdopodobnie dlatego, że analiza nie objęła chorych operowanych radykalnie, niewymagających leczenia uzupełniającego radioterapią. Dwu- i pięcioletnie przeżycia całkowite pacjentów radykalnie operowanych w latach 2004-2007 z rozpoznaniem płaskonabłonkowego raka płuca (79 pacjentów w stadium IA-IIB) na Oddziale Chirurgii Klatki Piersiowej Miejskiego Szpitala Zespolonego w Olsztynie, którzy nie otrzymali pooperacyjnej radioterapii, wyniosły odpowiednio 65\% i 48\% (mediana: 4,5 roku) (dane niepublikowane). Dwu-i pięcioletnie OS pacjentów, u których zastoso- wano leczenie radykalne (radioterapię/radiochemioterapię) w tutejszym ośrodku, wyniosły odpowiednio 43\% i 18\%.

Większość chorych leczonych radykalnie w tutejszym ośrodku była w stadium zaawansowania IIIA-IIIB (67\%). Wyniki badań klinicznych z randomizacją wykazały wydłużenie czasu przeżycia przy dodaniu chemioterapii do radioterapii, zarówno indukcyjnej jak i równoczasowej [10-14]. Standardem leczenia pacjentów z zaawansowaniem klinicznym IIIA-IIIB stało się więc kojarzenie radioterapii z chemioterapią $[10,11,15,16]$. Pięcioletnie przeżycia chorych w stadium IIIA-IIIB niedrobnokomórkowego raka płuca wahają się w granicach: 9-31\% [4, 10, 16-18]. W SP ZOZ MSW z Warmińsko-Mazurskim Centrum Onkologii w Olsztynie 5-letnie przeżycia całkowite pacjentów poddanych radiochemioterapii (w stadium IIIA-IIIB) w latach 2003-2006 wyniosły 13\% i pokrywają się z danymi z piśmiennictwa. W tutejszym ośrodku pacjenci z cechą N0 rokowali tak samo niezależnie od sposobu leczenia (samodzielna vs skojarzona radioterapia) $(p=0,76)$. Natomiast wszyscy chorzy (oprócz 5) z cechą $\mathrm{N}(+)$ otrzymali radiochemioterapię. Wyniki kilku badań z randomizacją [19, 20-22] i mataanaliza [23] wykazały przewagę radiochemioterapii jednoczasowej nad sekwencyjną, jednak w codziennej praktyce u ponad połowy pacjentów istnieją przeciwwskazania do tej formy leczenia [24]. W tutejszym ośrodku większość chorych w stadium IIIA-IIIB poddanych metodzie skojarzonej (102 pacjentów) otrzymała właśnie sekwencyjną radiochemioterapię; zaledwie 4 chorych otrzymało leczenie jednoczasowe. Statystyczne porównanie tych grup jest więc niemożliwe. Wcześniej opublikowane wyniki 
badania z randomizacją przeprowadzonego w tutejszym ośrodku dla grupy chorych z rozpoznaniem NSCLC w stopniu zaawansowania klinicznego IIIA i IIIB niekwalifikujących się do leczenia radykalnego wykazały lepsze 2-letnie OS pacjentów poddanych paliatywnej jednoczasowej radiochemioterapii w stosunku do pacjentów poddanych samodzielnej radioterapii (10 frakcji w dawce frakcyjnej 3 Gy), odpowiednio $24 \%$ vs $6 \%$ [6]. Pięcioletnie przeżycia pacjentów, którzy otrzymali radiochemioterapię, wyniosły $9 \%$. Natomiast spośród chorych poddanych samodzielnej radioterapii nikt nie przeżył 5 lat $(p=0,03)$ (dane niepublikowane). Wyniki te są oczywiście gorsze niż w przypadku stosowania radykalnej radiochemioterapii (2- i 5-letnie OS wyniosły 37\% i 13\%).

Wpływ dawki całkowitej radioterapii na przeżycia jest niejasny. Wcześniejsze doniesienia sugerowały, że podwyższenie dawki poprawia wyniki leczenia [25], jednak opublikowane w 2013 roku wyniki badania z randomizacją wykazały, że stosowanie wyższych dawek (74 Gy vs 60 Gy) przyczynia się do obniżenia czasu przeżycia całkowitego [26]. W przeprowadzonej w tutejszym ośrodku analizie nie wykazano istotnego wpływu dawki całkowitej ( $\leq 60 \mathrm{~Gy}$ $v s>60 \mathrm{~Gy}$ ) na OS pacjentów poddanych radykalnemu leczeniu $(p=0,54)$. Dwuletnie przeżycia były identyczne, ale po 3-letniej obserwacji wykazano tendencję do poprawy przeżyć przy zastosowaniu niższych dawek (5-letnie OS wyniosły $21 \%$ vs $16 \%$ ). Analiza retrospektywna nie uprawnia do wyciągania daleko idących wniosków. W opracowanym retrospektywnie materiale nie można jednoznacznie określić powodu stosowania różnych dawek u poszczególnych pacjentów. Niższą dawkę mogli otrzymać np. chorzy z dużą masą guza czy też osoby z mniejszym guzem, ale z niewydolnością oddechową, uniemożliwiającą podanie wyższych dawek radioterapii.

Matchtay i wsp. wykazali, iż przedłużony czas leczenia chorych z powodu miejscowo zaawansowanego NDRP ma wpływ na pogorszenie wyników przeżycia [27], natomiast wyniki naszej analizy nie potwierdzają wpływu czasu leczenia na czas całkowitego przeżycia wśród pacjentów poddanych radiochemioterapii. W tej grupie chorych czynnikiem mającym znamienny statystycznie wpływ na OS jest jedynie zajęcie węzłów chłonnych.

Rozpoznanie histopatologiczne w przypadku NDRP ma istotny wpływ na przeżycia (gorsze rokowanie w przypadku raka płaskonabłonkowego) [27]. Dwu- i pięcioletnie OS pacjentów poddanych radiochemioterapii z powodu płaskonabłonkowego raka płuca w tutejszym ośrodku wyniosły odpowiednio $36 \%$ i $10 \%$ (mediana 1,5 roku), a z powodu raka gruczołowego odpowiednio 52\% i 9,5\% (mediana 2,5 roku) (brak znamienności statystycznej).

Pięcioletnie przeżycia całkowite pacjentów z zaawansowaniem pT1-3 N0-2 leczonych chirurgicznie z uzupełniającą radioterapią wynoszą około $30 \%$ [28]. Przeżycia chorych leczonych operacyjnie $z$ następowym napromienianiem w tutejszym ośrodku były zgodne z danymi z literatury (5-letnie OS wyniosły 30\%).

Niniejsza analiza objęła wszystkich chorych z rozpoznaniem NDRP leczonych w latach 2003-2006. Niejednorodność badanej grupy oraz retrospektywny charakter analizy stanowiły pewne ograniczenia zastosowanej metody badawczej (zbyt mało zmiennych mających istotny wpływ na OS uniemożliwia przeprowadzenie analizy wieloczynnikowej).

\section{Wnioski}

Spośród analizowanych czynników w tutejszym ośrodku istotne statystycznie znaczenie w przeżyciach całkowitych u pacjentów z rozpoznaniem NDRP poddanych radioterapii miały: płeć, dawka napromieniania, stopień klinicznego zaawansowania, cecha $\mathrm{T}$, cecha $\mathrm{N}$, rozpoznanie histopatologiczne, czas trwania radiochemioterapii oraz zajęcie węzłów chłonnych.

W Polsce wciąż brakuje publikacji przedstawiających wyniki skuteczności leczenia w poszczególnych ośrodkach onkologicznych, natomiast przedstawiane w literaturze dane z międzynarodowych badań klinicznych dotyczą przeżyć całkowitych wyselekcjonowanej grupy chorych, dlatego trudno się do nich odnosić.

\section{Konflikt interesów: nie zgłoszono}

\section{Prof. dr hab. n. med. Sergiusz Nawrocki}

Uniwersyteckie Centrum Okulistyki i Onkologii

ul. Ceglana 35, Katowice

e-mail:sergiusz@cyberia.pl

Otrzymano: 3 września 2014 r.

Przyjęto do druku: 20 stycznia 2015 r.

\section{Piśmiennictwo}

1. Raporty na podstawie danych Centrum Onkologii http://85.128.14. 124/krn/.

2. Rzyman W. Rak płuca. Forum Medycyny Rodzinnej 2008; 2: 407-419.

3. Krzakowski M, Jassem J, Dziadziuszko Ri wsp. Nowotwory złośliwe płuca i opłucnej. W: Zalecenia postępowania diagnostyczno-terapeutycznego w nowotworach złośliwych 2011 rok. Gdańsk: Via Medica; 2011: 69-96.

4. Yang P, Allen MS, Aubry MC i wsp. Clinical features of 5,628 primary lung cancer patients: Experience at Mayo Clinic from 1997 to 2003. Chest 2005; 128: 452-462.

5. Ginsberg JR, Martini N. Surgical management of NSCLC. W: Pearson GF, Cooper JO, Deslauriers J i wsp. Thoracic surgery. Churchill-Livingstone, Philadelphia 2002: 837.

6. Nawrocki S, Krzakowski M, Wasilewska-Teśluk E i wsp. Concurrent chemotherapy and short course radiotherapy in patients with stage IIIA to IIIB non-small cell lung cancer not eligible for radical treatment: results of a randomized phase II study. J Thorac Oncol 2010; 5: $1255-1262$.

7. Gandara D, Narayan S, Lara PN Jr. i wsp. Integration of novel therapeutics into combined modality therapy of locally advanced non-small cell lung cancer. Clin Cancer Res 2005; 11: 5057-5062.

8. Naruke T, Goya T, Tsuchiva R i wsp. Prognosis and survival in resected lung carcinoma based on the international staging system. J Thorac Cardiovasc Surg 1998; 96: 440-447.

9. Goldstraw P, Crowley J, Chansky K i wsp. The IASLC Lung Cancer Staging Project: proposals for the revision of the TNM stage groupings in the forthcoming (seventh) edition of the TNM Classification of malignant tumours. J Thorac Oncol 2007; 2: 706-714.

10. Dillman RO, Seagren SL, Propert KJ i wsp. A randomized trial of induction chemotherapy plus high-dose radiation versus radiation alone in stage III non-small-cell lung cancer. N Engl J Med 1990; 323: 940-945. 
11. Le Chevalier T, Arriagada R, Quoix E i wsp. Radiotherapy alone versus combined chemotherapy and radiotherapy in nonresectable non-small-cell lung cancer: first analysis of a randomized trial in 353 patients. J Nat/ Cancer Inst 1991; 83: 417-423.

12. Schaake-Koning C, van den Bogaert W, Dalesio O i wsp. Effects of concomitant cisplatin and radiotherapy on inoperable non-small-cell lung cancer. N Engl J Med 1992; 326: 524-530.

13. Sause W, Kolesar P, Taylor S IV i wsp. Final results of phase III trial in regionally advanced unresectable non-small cell lung cancer: Radiation Therapy Oncology Group, Eastern Cooperative Oncology Group, and Southwest Oncology Group. Chest 2000; 117: 358-364.

14. Jeremić B, Miličić B, Milisavljević S. Radiotherapy alone vs. radiochemotherapy in patients with favorable prognosis of clinical stage IIIA non-small-cell lung cancer. Clin Lung Cancer 2013; 14: 172-180.

15. Pfister DG, Johnson DH, Azzoli CG i wsp. American Society of Clinical Oncology treatment of unresectable non-small-cell lung cancer guideline: Update 2003. J Clin Oncol 2004; 22: 330-353.

16. Furuse $\mathrm{K}$, Kubota $\mathrm{K}$ Kawahara $\mathrm{M}$ i wsp. Phase II study of concurrent radiotherapy and chemotherapy for unresectable stage III non-smallcell lung cancer. Southern Osaka Lung Cancer Study Group.J Clin Oncol 1995; 13: 869-875.

17. Dillman RO, Herndon J, Seagren SL i wsp. Improved survival in stage III non-small-cell lung cancer: seven-year follow-up of cancer and leukemia group B (CALGB) 8433 trial. J Natl Cancer Inst 1996: 88: 1210-1215.

18. Saitoh J, Saito Y, Kazumoto T i wsp. Concurrent chemoradiotherapy followed by consolidation chemotherapy with bi-weekly docetaxel and carboplatin for stage III unresectable, non-small-cell lung cancer: clinical application of a protocol used in a previous phase II study. Int J Radiat Oncol Biol Phys 2012; 82: 1791-1796.

19. Fournel $P$, Robinet $G$, Thomas $P$ i wsp. Randomized phase III trial of sequential chemoradiotherapy compared with concurrent chemoradiotherapy in locally advanced non-small-cell lung cancer: Groupe Lyon-Saint-Etienne d'Oncologie Thoracique-Groupe Francais de Pneumo-Cancerologie NPC 95-01 Study. J Clin Oncol 2005; 23: 5910-5917.
20. Furuse K, Fukuoka M Kawahara M i wsp. Phase Ill study of concurrent vs. sequential thoracic radiotherapy in combination with mitomycin, vindesine and cisplatin in unresectable stage III non-small cell lung cancer: five-year median follow-up results. J Clin Oncol 1999; 17: 2692-2699.

21. Curran WJ Jr, Paulus R, Langer CJ i wsp. Sequential vs. concurrent chemoradiation for stage III non-small cell lung cancer: randomized phase III trial RTOG 9410. J Nat/ Cancer Inst 2011; 103: 1452-1460.

22. Estelle R, Le Chevalier T, Auperin A i wsp. Sequential radio-chemotherapy (RT-CT) versus radiotherapy alone (RT) and concomitant RT-CT versus RT alone in locally advanced non-small cell lung cancer (NSCLC): Two meta-anayles using individual patent data (IPD) from randomized clinical Trials (RCTs). J Thorac Oncol 2007; 2: 309.

23. Aupérin A, Le Péchoux $C$, Rolland E i wsp. Meta-analysis of concomitant versus sequential radiochemotherapy in locally advanced non-smallcell lung cancer. J Clin Oncol 2010; 28: 2181-2190.

24. De Ruysscher D, Botterweck A, Dirx M i wsp. Eligibility for concurrent chemotherapy and radiotherapy of locally advanced lung cancer patients: a prospective, population-based study. Ann Oncol 2009; 20: 98-102.

25. Bradley J, Graham MV, Winter K i wsp. Toxicity and outcome results of RTOG 9311: a phase I-II dose-escalation study using three-dimensional conformal radiotherapy in patients with inoperable non-small-cell lung carcinoma. Int J Radiat Oncol Biol Phys 2005; 61: 318-328.

26. Bradley JD, Paulus R, Komaki Ri wsp. A rondomized phase III comparison of standard-dose (60Gy) versus high-dose (74Gy) conformal chemoradiotherapy \pm cetuximab for stage III non-small cell lung cancer: Results on radiation dose in RTOG 0617. J Clin Oncol 2013; 15: 458 .

27. Machtay M, Hsu C, Komaki R i wsp. Effect of overall treatment time on outcomes after concurrent chemoradiation for locally advanced non-small-cell lung carcinoma: analysis of the Radiation Therapy Oncology Group (RTOG) experience. Int J Radiat Oncol Biol Phys 2005; 63: 667-671.

28. Mayer R, Smolle-Juettner FM, Szolar D i wsp. Postoperative radiotherapy in radically resected non-small cell lung cancer. Chest 1997; 112: 954-959. 